\title{
The Effect of Parental Attention, Social Media and Religiosity on the Morals of Students
}

\author{
Endang Ekowati ${ }^{1}$, Nyayu Khodijah ${ }^{2}$, Abdurrahmansyah $^{3}$
}

DOI: $10.35445 /$ alishlah.v13i3.767

\begin{tabular}{l}
\hline Article Info \\
\hline Keywords: \\
Morals, \\
Parental attention, \\
Social media, \\
Religiosity
\end{tabular}

Kata kunci:

Akhlak,

Perhatian orang tua,

Media sosial,

Religiusitas

\begin{abstract}
The study aimed to determine the effect of parental attention, social media, and religiosity on adolescent morals at a Madrasah Aliyah Negeri, South Lampung. The research was quantitative. The population in the study was 450 students, with a proportional random sampling technique; the sample used was 82 students. The data collection method used was a questionnaire. The method of data analysis was done by descriptive analysis and path analysis. The study showed that first, the effect of parental attention on adolescent morals was $13 \%$ in the low category. Second, the influence of social media on adolescent morals was $32 \%$ in the medium category. Third, the influence of religiosity on adolescent morals was $53 \%$ in a strong category. And fourth, the correlation of the effect of parental attention, social media, and religiosity on adolescent morals simultaneously was $57 \%$. Thus, parental engagement, social media, and religiosity positively affected adolescent morals.
\end{abstract}

\begin{abstract}
Abstrak
Penelitian ini bertujuan untuk mengetahui pengaruh perhatian orang tua, media sosial dan religiusitas terhadap akhlak remaja di salah satu Madrasah Aliyah Negeri Lampung Selatan. Penelitian ini merupakan penelitian kuantitatif. Populasi dalam penelitian ini berjumlah 450 siswa, dengan teknik propotional random sampling maka sampel yang digunakan sebanyak 82 siswa. Metode pengumpulan data yang digunakan adalah kuesioner. Metode analisis data dilakukan dengan analisis deskriptif dan analisis jalur (path analysis). Penelitian ini menunjukkan bahwa pertama, pengaruh perhatian orang tua terhadap akhlak remaja sebesar 13\% dengan kategori rendah. Kedua, pengaruh media sosial terhadap akhlak remaja sebesar $32 \%$ dengan kategori sedang. Ketiga, pengaruh religiusitas terhadap akhlak remaja sebesar $53 \%$ dengan kategori kuat. Dan keempat, korelasi pengaruh pengaruh perhatian orang tua, media sosial dan religiusitas terhadap akhlak remaja secara simultan sebesar 57\%. Dengan demikian, perhatian orang tua, media sosial dan religiusitas berpengaruh positif terhadap peningkatan akhlak remaja.
\end{abstract}

\footnotetext{
${ }^{1}$ IAI An Nur Lampung, Indonesia

Email: endangekowati34@gmail.com

2 UIN Raden Fatah Palembang, Indonesia

Email: nyayukhodijah_uin@radenfatah.ac.id

3 UIN Raden Fatah Palembang, Indonesia

Email: abdurrahmansyah_uin@radenfatah.ac.id
} 


\section{INTRODUCTION}

In recent years, the moral and behavioral demoralization of the nation's youth has escalated, including high rates of corruption, nepotism, drug addiction, and crime. There was a lack of concern for virtues like politeness, friendliness, tolerance, humility, helpfulness, and social solidarity, to name just a few (Zubaedi, 2009). This problem became a homework assignment, necessitating collaboration across several groups, including the government, parents, the community, and schools, to be solved. Teenagers' values are deteriorating right now, whether they live in big cities or rural places. Drugs, brawls, and bullying were just incidents that grew in frequency, but their quality also grew. Juvenile delinquency, which began as school brawls and school fights, has evolved into more serious criminal activities like theft, rape, and drug usage. Teenage crime and delinquency required extra attention today. (Munthoha \& Wekke, 2017).

Based on data in the field through television and other mass media, delinquency and criminal behavior among teenagers continue to increase from day to day. The National Police, in their report, revealed that in 20073,145 juveniles were involved in criminal behavior. In 2008 it became 3,280, and in 2009, it became 4,213 teenagers (Munthoha \& Wekke, 2017; Polri, 2007).

In 2013 the number of juvenile delinquency in Indonesia reached 6,325 cases, while in 2014, the number reached 7,007 cases, and in 2015 it reached 7,762 cases. This meant that from 2013 2014 there was an increase of 10.7\%. The cases consisted of various juvenile delinquency cases, including theft, murder, promiscuity, and drugs. The increase can be predicted in 2016 to reach 8597.97 cases, and in 2017 it is predicted to reach 9523.97 cases, 2018 as many as 10549.70 cases, 2019 reaching 11685.90 cases, and 2020 reaching 12944.47 cases. It had increased annually by $10.7 \%$ (Munthoha \& Wekke, 2017; Statistik, 2015). Juvenile delinquency until now was increasingly worrying, which needed to be a concern for stakeholders, including parents, by providing guidance.

Moral development was significant to be instilled from an early age. Children's morals improve better in the family, school, and community environment, so they become human beings with noble character. However, educating children to be pious and have noble character was not easy, especially in this era of rapid technological development. There were so many factors that hindered the improvement of children's morals, including the lack of parental attention to children, lack of example, environmental influences, and the influence of rapid technological developments, especially the development of technology and information such as gadgets and social media, and many others (Firmansyah, 2020). With a device in their hands, children can access all positive and negative information. Children still cannot distinguish between good and bad content, so they need to get parents' attention and education from schools.

Several previous studies were conducted, including juvenile delinquency influenced by family conditions, namely parental attention (Munthoha \& Wekke, 2017; Sumara et al., 2017). In addition, religiosity was also one of the factors that cause juvenile delinquency. In other words, adolescents with high levels of religiosity tended to behave by the values and norms in society and vice versa (Aviyah \& Farid, 2014; Nasikhah, 2013; Palupi, 2013; Robana et al., 2012). Likewise, social media also affects adolescent morals (Kasetyaningsih \& Hartono, 2017). The research was expected to determine the effect of parental attention, social media, and religiosity on students' morals.

\section{METHOD}

The type of research was quantitative research. A questionnaire did the data collection. The population in the study were all students of Madrasah Aliyah Negeri 1 Kalianda South Lampung totaling 450 students. With the proportional random sampling technique, the sample used was 82 students. The questionnaire instrument before being used was tested for validity with the SPSS version 18.0 application program and reliability with an alpha scale (Alpha Cronbach). Some of the questionnaires submitted were managing learning activities, helping to solve children's difficulties in learning, the use of social media, social media accounts, beliefs, religious practices, morals, and others. Then the data were analyzed using descriptive analysis and path analysis. 
Al- Ishlah: Jurnal Pendidikan, December 2021, vol. 13 (3), Pages 2982-2989

Endang Ekowati, Nyayu Khodijah, Abdurrahmansyah

\section{FINDINGS AND DISCUSSION \\ Variable Data Description}

a. Parental attention data

Table 1. Parental attention

\begin{tabular}{lc}
\hline \multicolumn{1}{c}{ Description } & Score \\
\hline Mean & 57,41 \\
Median & 57,00 \\
Modus & 52 \\
Std. Deviation & 6,733 \\
\hline
\end{tabular}

Based on table 1, it was known that the average score obtained by research respondents who answered the research questionnaire about the parental attention of students at MAN 1 Kalianda, South Lampung was 57.41 . The highest score obtained by the respondents was 72, and the lowest score was 41 . The score obtained by the most respondents on the parental attention questionnaire was 52, as many as 8 (eight) people or $9.7 \%$, while the other scores obtained by respondents were evenly distributed with the median value at score 57 . These data indicated that the average score and the score that often appeared with the median score were not much different. This illustrated that the frequency distribution of the variable score for the parental attention of students at MAN 1 Kalianda South Lampung tended to be normally distributed.

In the course of their observations, it was discovered that students' parental involvement in learning activities included, among other things, providing their children with the writing supplies they needed, encouraging self-discipline in them, and monitoring the results of their educational endeavors. (Ekowati, 2021). This meant that most parents of students had paid attention to their children.

b. Description of social media use

Table 2. Use of social media by students

\begin{tabular}{ll}
\hline \multicolumn{1}{c}{ Description } & \multicolumn{1}{c}{ Score } \\
\hline Mean & 62,93 \\
Median & 63,50 \\
Modus & 65 \\
Std. Deviation & 7,749 \\
\hline
\end{tabular}

Based on table 2, it was known that the average score obtained by research respondents who answered research questionnaires about the use of social media was 62.93. The highest score obtained by respondents was 79, and the lowest score was 50. The most scores obtained by respondents on the social media use questionnaire was 65 as many as 6 (six) people or $7.3 \%$. In contrast, the other scores obtained by respondents were evenly distributed with a median value of score 63.50. The data showed that the average score and the score that often appeared with the median score were not much different. This illustrated that the frequency distribution of scores for the variable of social media users tended to be normally distributed.

Based on the observations, it was found that the madrasah principal tried to create a conducive online learning system in his madrasa environment, such as implementing communication through WhatsApp Groups to maintain harmony between the madrasa principal and teachers and students. Madrasas also provided a lot of information regarding academic activities and academic calendars through social media such as Whatsapp Group, Facebook, and Instagram. This was done to make it easier for madrasa servants to serve students (Ekowati, 2021).

Furthermore, social media was quite good, such as using social media to support learning activities and stay in touch with family, peers, and teachers. Some students used social media for a teen clothing business which parents positively supported. In addition, it is used to obtain information on the latest developments from the outside world. 
c. Description of the students' religiosity

Table 3. Religiosity of students

\begin{tabular}{lll}
\hline \multicolumn{1}{c}{ Description } & \multicolumn{1}{c}{ Score } \\
\hline Mean & 68,17 & \\
Median & 67.00 & \\
Modus & 54 & \\
Std. Deviation & 13,338 & \\
\hline
\end{tabular}

Based on table 3, it was known that the average score obtained by research respondents who answered research questionnaires about the religiosity of students at MAN 1 Kalianda South Lampung was 68.17. The highest score obtained by respondents was 94, and the lowest score was 46. The most scores obtained by respondents on the student religiosity questionnaire were 54 as many as 5 (five) people or $6 \%$. In contrast, the other scores obtained by respondents were evenly distributed with a median score of 67 . These data indicate that the average score and the score that often appeared with the median score were not much different. This illustrated that the frequency distribution of students' scores on the religiosity variable tended to be normally distributed.

Based on observations, it was known that the extracurricular agenda that played a very important role in the formation of a religious soul for students was reading the Qur'an before starting the lesson; Friday Charity with infaq and alms; cleanliness on Saturdays; Duha prayer, and Zuhur prayer (Ekowati, 2021).

d. Description of students' morals

Table 4. Morals of students

\begin{tabular}{lll}
\hline \multicolumn{1}{c}{ Description } & \multicolumn{1}{c}{ Score } \\
\hline Mean & 68,95 & \\
Median & 68.00 & \\
Modus & 61 & \\
Std. Deviation & 8,216 & \\
\hline
\end{tabular}

Based on table 4, it was known that the average score obtained by research respondents who answered research questionnaires about the morals of students at MAN 1 Kalianda South Lampung was 68.95. The highest score obtained by respondents was 84 , and the lowest score was 54 . The most scores obtained by respondents on the student morals questionnaire were 61 , while the other scores obtained by respondents were evenly distributed with a median score of 68 . These data indicated that the average score and the score that often appeared with the median score were not much different. This illustrated that the frequency distribution of the students' moral variable scores tended to be normally distributed.

\section{Normality Test}

1. Table 5. Summary of Normality Testing Analysis

\begin{tabular}{clccc}
\hline No & \multicolumn{1}{c}{ Variables } & Sig. KS & $\boldsymbol{\alpha}=\mathbf{o , 0 5}$ & Description \\
\hline 1 & Parental Attention $\left(\mathrm{X}_{1}\right)$ & 0,639 & 0,05 & Normal \\
2 & Social Media $\left(\mathrm{X}_{2}\right)$ & 0,451 & 0,05 & Normal \\
3 & Religiosity $\left(\mathrm{X}_{3}\right)$ & 0,784 & 0,05 & Normal \\
4 & Moral $(\mathrm{Y})$ & 0,498 & 0,05 & Normal \\
\hline
\end{tabular}




\section{Hypothesis}

a. First hypothesis

Table 6. The effect of parental attention on the morals of students

\begin{tabular}{ccccc}
\hline \multicolumn{5}{c}{ Model Summary $^{\mathbf{c}}$} \\
\hline Model & $\mathrm{R}$ & R Square & Adjusted R & Std. Error of the \\
& & & Square & Estimate \\
1 & $0,371 \mathrm{a}$ & 0,138 & 0,127 & 7,677
\end{tabular}

In table 6, it was known that the effect of parental attention on the morals of the students was 0.371 , or it can be said that the change in the morals of students was affected by the variable of parental attention of $13.8 \%$ which was categorized as a low effect. At the same time, the remaining $86,2 \%$ was affected by other variables outside the model. Thus it can be concluded that parental attention affected the morals of students even though at a very low level, so the hypothesis in the parental study attention affected the morals of students can be verified and the research objectives were achieved.

b. The second hypothesis

Table 7. The effect of the use of social media on the morals of students Model Summary ${ }^{b}$

\begin{tabular}{ccccc}
\hline Model & $\mathrm{R}$ & R Square & $\begin{array}{c}\text { Adjusted R } \\
\text { Square }\end{array}$ & $\begin{array}{c}\text { Std. Error of the } \\
\text { Estimate }\end{array}$ \\
& & & 0,316 & 6,796 \\
\hline
\end{tabular}

In table 7, it was known that the effect of using social media on the morals of students was 0.569, so it can be said that the correlation level was moderate or can be interpreted as changing students' morals was affected by the variable use of social media by $32.4 \%$ categorized as a moderate effect. Thus, it can be concluded that the use of social media had been proven to be significant in affecting the morals of students, so the hypothesis which read the use of social media affected the morals of students can be verified, and the research objectives were achieved.

c. Third hypothesis

Table 8. The effect of religiosity on the morals of students

\begin{tabular}{ccccc}
\hline \multicolumn{5}{c}{ Model Summary $^{\mathbf{b}}$} \\
\hline Model & $\mathrm{R}$ & R Square & Adjusted R & Std. Error of the \\
& & & Square & Estimate \\
\multirow{2}{*}{1} & $0,730^{\mathrm{a}}$ & 0,532 & 0,526 & 5,654 \\
\hline
\end{tabular}

In table 9, it was known that the effect of religiosity on the morals of students was 0.730, or it can be said that the change in students' morals was affected by the religiosity variable of $53.2 \%$, which was categorized as strong/high influence. Thus, it can be concluded that religiosity had been proven to be significant in affecting the morals of students, so the hypothesis read religiosity affected the morals of students can be verified, and the research objectives were achieved. 
d. Fourth hypothesis

\begin{tabular}{ccccc}
$\begin{array}{c}\text { Table 9. Effect of parental attention, use of social media } \\
\text { and religiosity together on the morals of students }\end{array}$ \\
\hline \multicolumn{5}{c}{ Model Summary } \\
\hline Model & $\mathrm{R}$ & R Square & $\begin{array}{c}\text { Adjusted R } \\
\text { Square }\end{array}$ & $\begin{array}{c}\text { Std. Error of the } \\
\text { Estimate }\end{array}$ \\
& & \multicolumn{4}{c}{0,561} & 5,445 \\
\hline
\end{tabular}

In table 9, it was known that the effect of parental attention, use of social media, and religiosity together on the morals of students was 0.760 , or it can be said that changes in students' morals were affected by parental attention, use of social media and religiosity together on the morals of the students by $57.7 \%$ which was categorized as having a strong/high influence. In contrast, other variables outside the model influenced the remaining $42.3 \%$. Thus, it can be concluded that there was an effect of parental attention, the use of social media, and religiosity together on the morals of the students of Madrasah Aliyah Negeri (MAN) 1 Kalianda South Lampung. Or it can be said that if the attention of parents, the use of social media and religiosity together was increasing, it will be followed by an increase in the morals of students. Thus it can be understood that parental attention, use of social media, and religiosity together had a positive effect on the morals of students.

\section{Parental attention to the morals of students}

An increase will follow the increasing parental attention towards their children in the morals of students. The results of the research found were in line with the research of Firmansyah (2020), Saputri (2015), and Hannum (Hsb, 2017), which stated that there was a positive and significant effect of parental attention on improving the morals of students. In another study, juvenile delinquency was caused by a lack of parental attention (Sagala, 2018; Siregar, 2018). Parents have a very important role in developing a child's personality. The loving care for children and education about life values, both religious and socio-cultural, were conducive factors in preparing children to become healthy individuals and members of society.

The family was seen as an institution (institution) that can meet human (human) needs, especially the need for personality development and the development of the human race. When linking the role of parents with efforts to meet individual needs in the family from Maslow quoted by Syamsu Yusuf (2011), the family was the first institution that could meet these needs. Through good care and treatment from parents, children can fulfill their basic physical-biological and sociopsychological needs if they have gained a sense of security, social acceptance, and self-esteem.

Parents in a happy family are very important for the emotional development of its members (especially children). This happiness was obtained when parents could play their functions well. The basic function of the family was to provide a sense of belonging, security, affection and develop good relationships among family members. The relationship of love and affection in the family was not limited to feelings but also involved maintenance, a sense of responsibility, attention, understanding, and the growth and development of the child he loves. Parents had a very important role in the growth and development of children to become healthy, intelligent, presentable, independent, and noble individuals. Along with the phase of children's development, the role of parents also changes (Yusuf, 2011).

\section{The use of social media on the morals of students}

The use of media had a positive effect on the morals of students. The results of the research found were in line with the research of Yana (2020), Utami (2020), and Aditiawan (2019), which stated that there was a significant relationship between the intensity of social media use and the morals of students. On the other hand, this research differed from Khoerunnisa's (2019) ) research that the intensity of the use of social media had a significant negative relationship on the morals of 
students at school. Even social media contributed to increasing un-commendable morals in students (Nurkarima, 2018).

Social media had progressed very rapidly. Not only as a medium of communication but also as a place to find friends, build a community and even transform into a place of business, so the existence of social media among teenagers became problematic. If a teenager could use it wisely, it would positively impact him. Meanwhile, if teenagers cannot use it wisely, it will have a negative effect on them. Things that can be caused through the features presented on social media that had negative effects on adolescent morals include not caring about the life around them, making teenagers neglect their obligations, criminal behavior, pornography, and minimal manners. However, if teenagers could address the benefits of using social media, these negative things can become positive things.

The progress of social media was not just providing information but has an effect on the process of forming the morals of students. The tendency or frequency of using social media without guidance and restrictions from adults made them feel free. Without realizing it, they began to imitate what they saw. Moreover, students at this time only judged from style or style, not paying attention to the impact of social media, which had an impact on the process of moral formation (Khoerunnisa, 2019).

\section{Religiosity to the morals of students}

The religiosity of students was increasing; an increase will follow it in the morals of students. The results of the research found were in line with the research of Ummah (2021), Jannah (2017), and Suharman (2020), which found that religiosity was an important factor in the morals of students, and its contribution was very strong. Religiosity was an important aspect in shaping students' morals (Annur et al., 2018). A person's attitude was very closely related to religiosity. It can provide a way for humans to achieve a sense of security from anxiety in dealing with life's problems so that when faced with a dilemma or conflict, individuals will use considerations on the values of each. Each religion wherever the person was in any condition (Tahaha \& Rustan, 2017). Religion functioned to guide and direct humans to be aware of their existence as completely limited humans and develop an attitude of faith and piety to omnipotent God (Fatimah, 2021).

\section{CONCLUSION}

The study concluded that parental attention, use of social media, and student religiosity had an effect on improving students' morals. These results were based on the contribution of parental attention by $13 \%$ (low), social media use by $32 \%$ (moderate), religiosity by $53 \%$ (strong), and if all three contribute stimulants by $57 \%$ (strong). Thus, schools needed to develop aspects of religiosity at school and parents at home to optimize attention to their children

\section{REFERENCES}

Aditiawan, A. R. (2019). Hubungan Intensitas Penggunaan Media Sosial dengan Akhlak Peserta Didik Kelas XI SMA Negeri 6 Sidrap. IAIN Parepare.

Ana Rizki, S. (2015). Pengaruh Perhatian Orang Tua Terhadap Akhlak Siswa Mi Nurul Hidayah Majalangu Kecamatan Watukumpul Kabupaten Pemalang Tahun Pelajaran 2014/ 2015 (pp. 1-84). UIN Walisongo.

Annur, A., Kurnianto, R., \& Rohmadi, R. (2018). Penerapan Karakter Religius pada Peserta Didik di MTs Muhammadiyah 3 Yanggong Ponorogo. TARBAWI: Journal on Islamic Education, 2(2), 1-11.

Aviyah, E., \& Farid, M. (2014). Religiusitas, kontrol diri dan kenakalan remaja. Persona: Jurnal Psikologi Indonesia, 3(02).

Ekowati, E. (2021). Observasi.

Fatimah, F. (2021). Implementasi Budaya Religius dalam Membina Akhlak Siswa di MI Rahmatullah Kota Jambi. Jurnal Pendidikan Guru, 2(1).

Firmansyah, A. (2020). Pengaruh Perhatian Orang Tua Terhadap Peningkatan Akhlak Anak. Alim| Journal of Islamic Education, 2(1), 139-150. 
Hsb, R. H. (2017). Pengaruh perhatian orangtua terhadap akhlak anak di lingkungan III Banjar Raja Kecamatan Barumun Kabupaten Padang Lawas. IAIN Padangsidimpuan.

Humyana, Y. (2020). Pengaruh Intensitas Penggunaan Media Sosial terhadap Akhlak Siswa di Sekolah SMPN 2 Waringinkurung. UIN SMH BANTEN.

Jannah, M. (2017). Pengaruh Religiusitas Terhadap Akhlak Siswa Kelas XI Di Madrasah Aliyah Negeri Tempel (MAN 5) Sleman Yogyakarta.

Kasetyaningsih, S. W., \& Hartono, H. (2017). Dampak Sosial Media Terhadap Akhlaq Remaja. DutaCom, 13(1), 1-10.

Khoerunnisa, P. (2019). Intensitas penggunaan media sosial pengaruhnya terhadap akhlak peserta didik di sekolah: penelitian di Kelas X SMA 3 PGRI Kota Bandung. Fakultas Tarbiyah dan Keguruan.

Munthoha, P. Z., \& Wekke, I. S. (2017). Pendidikan Akhlak Remaja bagi Keluarga Kelas Menengah Perkotaan. Cendekia: Journal of Education and Society, 15(2), 241. https://doi.org/10.21154/cendekia.v15i2.1153

Nasikhah, D. (2013). Hubungan antara tingkat religiusitas dengan perilaku kenakalan remaja pada masa remaja awal. Universitas Airlangga.

Nurkarima, N. (2018). Pengaruh Penggunaan Media Sosial Terhadap Akhlakul Karimah dan Akhlakul Madzmumah Siswa Di SMAN 1 Kauman Tahun Ajaran 2017/2018.

Palupi, A. O. (2013). Pengaruh religiusitas terhadap kenakalan remaja. Educational Psychology Journal, 2(1).

Polri. (2007). Analisa dan Evaluasi Situasi Kamtibmas Tahun 2007; 2008 Dan 2009.

Robana, R., Hikmawati, F., \& Ningsih, E. (2012). Hubungan Antara Religiousitas Dengan Kenakalan Remaja Pada Siswa Kelas XI MAN Surade Kabupaten Sukabumi. Psympathic: Jurnal Ilmiah Psikologi, 5(2), 655-666.

Sagala, A. A. (2018). Pengaruh Perhatian Orang Tua Terhadap Perilaku Kenakalan Remaja Pada Peserta Didik Dalam Perspektif Ilmu Pendidikan Agama Islam DI SMP MUHAMMADIYAH 1 MALANG.

Siregar, R. K. (2018). Perhatian orangtua terhadap pembinaan akhlak remaja di Kelurahan Aek Tampang Kecamatan Padangsidimpuan Selatan.

Statistik, B. P. (2015). Profil Kenakalan Remaja; Study di Lembaga Permasyarakatan Anak Blitar, Tangerang, Palembang dan Kutoarjo.

Suharman, S. (2020). Pengaruh Relegiusitas Terhadap Akhlak Remaja. Jurnal PAI Raden Fatah, 2(2), 171-182.

Sumara, D. S., Humaedi, S., \& Santoso, M. B. (2017). Kenakalan remaja dan penanganannya. Prosiding Penelitian Dan Pengabdian Kepada Masyarakat, 4(2).

Tahaha, H., \& Rustan, E. (2017). Orientasi Religiusitas dan Efikasi Diri dalam Hubungannya dengan Kebermaknaan Pendidikan Agama Islam pada Mahasiswa IAIN Palopo. Jurnal Studi Agama Dan Masyarakat, 13(2), 163. https://doi.org/10.23971/jsam.v13i2.551

Ummah, N. K., \& Khuriyah, K. (2021). Hubungan antara Religiusitas dan Pendidikan Karakter di Rumah terhadap Akhlak Siswa di Madrasah Tsanawiyah Negeri Surakarta. Cendekia: Jurnal Pendidikan Dan Pembelajaran, 15(1), 117-127.

Utami, M. P. (2020). Pengaruh penggunaan media sosial terhadap akhlak siswa di mts tarbiyah islamiyah kerkap. IAIN BENGKULU.

Yusuf, S. (2011). Perkembangan Peserta Didik. Raja Grafindo Persada.

Zubaedi. (2009). Memperkuat Dimensi Pendidikan Moral: Kata Pengantar (M. Lubis (ed.)). Pustaka Pelajar. 